\title{
Perlindungan Konsumen Pengguna Investasi Ilegal Vtube Berdasarkan Undang-Undang Nomor 21 Tahun 2011 tentang Otoritas Jasa Keuangan
}

\author{
Tamara Fransisca Jamal ${ }^{1 *}$, Puti Priyana ${ }^{2}$ \\ 1,2 Fakultas Hukum, Universitas Singaperbangsa Karawang, Indonesia \\ Jl. HS Ronggowaluyo, Teluk Jambe, Karawang, Jawa Barat, 41361, Indonesia. \\ *Correspondence email: tamarafransisca780@gmail.com, puti.priyana@fh.unsika.ac.id
}

\begin{abstract}
Abstrak. Perkembangan investasi saat ini semakin pesat karena adanya kemajuan teknologi, kemajuan ini menciptakan kemudahan dalam berinvestasi dengan adanya aplikasi investasi. Kemudahan tersebut disalahgunakan oleh oknum-oknum tertentu yang menyebabkan kerugian pada masyarakat dengan adanya investasi ilegal. Tahun 2020 Indonesia digemparkan oleh adanya virus corona yang mewabah di seluruh dunia. Hal ini menyebabkan pertumbuhan perekonomian semakin menurun. PT. Future View Tech meluncurkan aplikasi bernama Vtube yang dijadikan masyarakat sebagai alat penghasil uang dengan mudah. Vtube merupakan salah satu aplikasi investasi yang dinyatakan sebagai investasi ilegal oleh OJK. Penelitian ini bertujuan untuk mengetahui penyebab yang melatarbelakangi aplikasi Vtube disebut sebagai investasi ilegal dan untuk mengetahui peran OJK dalam memberikan perlindungan hukum kepada pengguna aplikasi Vtube. Metode yang digunakan dalam penelitian ini menggunakan yuridis normatif. Hasil dari penelitian ini adalah Vtube merupakan aplikasi investasi ilegal karena menjalankan suatu kegiatan usaha diluar dari Izin Usaha Industri (IUI) yang dimilikinya, peran OJK dalam memberikan perlindungan atas investasi ilegal yaitu diatur dalam Pasal 28 sampai dengan Pasal 30 UU OJK dan OJK memberikan tindakan preventif dan represif.
\end{abstract}

Kata Kunci: Investasi Ilegal, Vtube, Otoritas Jasa Keuangan

\begin{abstract}
The development of investment is currently growing rapidly due to technological advances, this progress has made it easier to invest with investment applications. This facility is misused by certain individuals who cause harm to the community due to illegal investment. In 2020, Indonesia was shocked by the corona virus that has spread throughout the world. This causes economic growth to decline. PT. Future View Tech launched an application called Vtube which is used by the public as an easy money-making tool. Vtube is an investment application declared as an illegal investment by the OJK. This study aims to determine the reasons behind the Vtube application called illegal investment and to determine the role of the OJK in providing legal protection to Vtube application users. The method used in this research is normative juridical. The result of this research is that Vtube is an illegal investment application because it carries out a business activity outside of its Industrial Business License (IUI), OJK's role in providing protection against illegal investment is regulated in Article 28 to Article 30 of the OJK Law and OJK provides preventive action. and repressive.
\end{abstract}

Keywords: Illegal Investment, Vtube, Legal Protection, Financial Fervices Authority

\section{PENDAHULUAN}

Pada tahun 2020 Indonesia digemparkan oleh adanya Corona Virus Disease 2019 (COVID-19) yang memberikan dampak buruk bagi kesehatan dan juga perekonomian negara. Penyebaran COVID-19 ini sangatlah cepat dan tidak terkendali, serta menimbulkan dampak negatif bagi sistem perekonomian Indonesia. Maka dari itu pemerintah Indonesia mengeluarkan kebijakan Pembatasan Sosial Berskala Besar (PSBB) guna untuk meminimalisir penyebaran virus ini. Akan tetapi dampak dari kebijakan PSBB yang dikeluarkan oleh pemerintah ini menimbulkan permasalahan-permasalahan bagi masyarakat dan negara. Permasalahan yang diakibatkan oleh COVID-19 bagi masyarakat yaitu banyak pekerja yang terkena Pemutusan Hubungan Kerja (PHK) yang mengakibatkan tingkat pengangguran di Indonesia semakin tinggi dan permasalahan bagi negara yaitu keuangan negara menjadi defisit.

Dengan bertambahnya tingkat pengangguran ini banyak masyarakat yang kesulitan untuk mencukupi kebutuhan sehari-harinya, kemudian pada bulan April 2020 muncul sebuah aplikasi bernama Vtube yang dikeluarkan oleh PT. Future View Tech, dimana aplikasi tersebut menawarkan kemudahan bagi penggunanya untuk mendapatkan penghasilan hanya dengan menonton video dan iklan yang ada di aplikasi tersebut. Persyaratan pendaftaran untuk menjadi pengguna atau anggota aplikasi Vtube ini bisa dikatakan cukup mudah, yaitu hanya dengan mengunggah foto Kartu Tanda Penduduk (KTP) sudah bisa menjadi anggota aplikasi Vtube. Akibat dari adanya penawaran tersebut banyak masyarakat yang tergiur untuk menggunakan aplikasi Vtube karena kemudahan dan keuntungan yang akan didapatkan.

Secara umum aplikasi Vtube ini merupakan aplikasi yang berjalan di bidang investasi, karena aplikasi tersebut menawarkan keuntungan berupa dana. Katan ivestasi berasal dari invest yang artinya menananam atau 
menginvestasikan uang atau modal. ${ }^{1}$ Akibat dari semakin canggihnya kemajuan teknologi semakin banyak pula potensi kejahatan, salah satunya kejahatan di bidang investasi yaitu maraknya investasi ilegal yang tidak terdaftar dalam Otoritas Jasa Keuangan (OJK). Akan tetapi pada bulan Juli 2020 aplikasi Vtube ini dinyatakan sebagai aplikasi ilegal oleh Otoritas Jasa Keuangan (OJK). Aplikasi Vtube ini ditetapkan sebagai aplikasi investasi ilegal karena tidak memiliki izin untuk melakukan kegiatan investasi. Investasi ilegal pada umumnya menggunakan skema piramid atau dikenal dengan skema Ponzi, Money game, Praktik penggandaan uang, Arisan berantai, bisnis berkedok MLM, Investasi berantai, dan lain-lain. ${ }^{2}$

Berdasarkan hasil uraian latar belakang tersebut diatas, penulis tertarik untuk memetakan rumusan masalahnya yaitu Bagaimana faktor penyebab yang melatarbelakangi aplikasi Vtube disebut sebagai investasi ilegal?, Bagaimana peran Otoritas Jasa Keuangan dalam memberikan perlindungan hukum kepada pengguna aplikasi Vtube?. Maksud dan tujuan penelitian tersebut bertitik tolak pada permasalahan yang teridentifikasi, yaitu untuk mengetahui bagaimana faktor penyebab yang melatarbelakangi aplikasi Vtube disebut sebagai investasi ilegal?, dan untuk mengetahui peran Otoritas Jasa Keuangan (OJK) dalam memberikan perlindungan hukum kepada pengguna aplikasi Vtube?

\section{METODE}

\section{Pendekatan dan Spesifikasi Penelitian}

Dalam penelitian ini menggunakan metode penelitian yuridis normatif. Yuridis Normatif yaitu metode yang meneliti bahan pustaka atau bahan sekunder. ${ }^{3}$ Metode ini dilakukan dengan cara mengumpulkan data mealui pengkajian bahan kepustakaan atau data sekunder Yng meliputi bahan hukum primer. Bahan hukum primer yaitu bahan penelitian yang berasal dari perundang-undangan yang berpaut dengan judul dan permasalahan yang telah dirumuskan dalam penelitian ini.

Spesifikasi penelitian ini adalah deskriptif analisis, yaitu untuk memberikan gambaran mengenai peraturan perundang-undangan yang berlaku dikaitkan dengan teori-teori hukum dan pelaksanaan hukum positif yang berkaitan dengan permasalahan. ${ }^{4}$ Analisis yang dimaksud adalah terhadap data primer dan data sekunder yang berkaitan dengan perlindungan hukum yang diberikan Otoritas Jasa Keuangan kepada pengguna Vtube atas investasi ilegal, selanjutnya dianalisis menggunakan perundang-undangan dan teori-teori yang relevan.

\section{Sumber Data dan Teknik Pengumpulan Data}

Sumber data yang digunakan yaitu data primer dan data sekunder. Teknik pengumpulan data yang digunakan adalah metode penelitian studi kepustakaan dengan mengumpulkan informasi dan data secara mendalam melalui berbagai literatur, buku, jurnal, dan referensi lainnya.

\section{Analisis Data}

Dalam penelitian ini hasil penelitian yang telah terkumpul dan dianalisis secara deskriptif kualitatif, yaitu seluruh data baik primer dan data sekunder diklasifikasikan atau dikelompokkan sesuai dengan permasalahan kemudian dianalisis dengan teori dan konsep yang relevan. Metode analisis data yang digunakan agar penulis mendapatkan kejelasan masalah yang dibahas.

\section{Lokasi Penelitian}

Lokasi dari penelitian ini dilakukan di wilayah hukum DKI Jakarta, karena merupakan lokasi PT. Future View Tech pemilik aplikasi Vtube.

\section{HASIL DAN PEMBAHASAN}

Dewasa ini seiring dengan berkembangnya zaman yang menghasilkan kemudahan-kemudahan bagi keberlangsungan kehidupan manusia terutama dibidang teknologi dan informasi. Semakin pesat perkembangan teknologi dan informasi semakin banyak pula inovasi-inovasi yang muncul khususnya disektor perekonomian salah satunya yaitu dibidang investasi. Investasi merupakan sebuah kegiatan menyimpan dan/atau penanaman modal sejumlah dana pada suatu perusahaan atau proyek tertentu dan di periode tertentu dengan harapan penyimpanan

1 Hasan Shadily, dalam, Ana Rokhmatussa'dyah dan Suratman, Hukum Investasi dan Pasar Modal, Jakarta:Sinar Grafika.2011. hlm.3

${ }^{2}$ Fitria Rahmadani, Paramita Prananingtyas, Siti Mahmudah. "PERLINDUNGAN HUKUM TERHADAP INVESTOR OLEH OTORITAS JASA KEUANGAN DALAM HAL TERJADI INVESTASI ILEGAL (STUDI KASUS PT GOLDEN TRADERS INDONESIA SYARIAH)”. DIPONEGORO LAW REVIEW. Volume 5, Nomor 2, Tahun 2016.hlm.2.

${ }^{3}$ Soerdjono Soekanto, dkk. Penelitian Hukum Normatif Suatu Tinjauan Singkat. Jakarta: Raja Grafindo Persada. 1994. hlm. 26.

${ }^{4}$ Roni Hanitijo Soemitro, Metode Penelitian Hukum dan Jurimetri, Jakarta: Ghalia Indonesia, 1988. hlm. 35. 
dan/atau penanaman modal tersebut dapat memberikan keuntungan atau peningkatan nilai investasi. Investasi merupakan sebuah komitemen terhadap sejumlah dana atau sumber daya lainnya yang dilakukan pada zaman ini yang tujuannya untuk mendapatkan suatu keuntungan dimasa yang akan datang. ${ }^{5}$

Saat ini banyak inovasi-inovasi terbaru dalam bidang investasi, salah satunya ialah investasi berbasis aplikasi online yang memudahkan masyarakat untuk melakukan suatu investasi. Sebelumnya investasi online berbasis aplikasi ini harus di daftarkan terlebih dahulu kepada Otoritas Jasa Keuangan (OJK) untuk memiliki izin operasional aplikasi yang legal. Akan tetapi masih banyak juga aplikasi investasi online yang nakal karena tidak memiliki izin dari Otoritas Jasa Keuangan (OJK) yang menjadikan aplikasi tersebut aplikasi ilegal. Salah satu investasi online berbasis aplikasi yang sedang banyak diminati oleh masyarakat Indonesia saat ini yaitu aplikasi Vtube yang di kelola oleh PT. Future View Tech. Aplikasi Vtube merupakan suatu aplikasi investasi yang menggunakan sistem media online dalam menjalankan praktik investasinya dengan melalui cara menawarkan paket investasi kepada masyarakat hanya dengan menonton video dan iklan yang ada pada aplikasi Vtube. Dan persyaratan untuk menjadi member atau anggota aplikasi Vtube ini bisa dikatakan cukup mudah hanya dengan menngunggah foto Kartu Tanda Penduduk (KTP) beserta foto selfie calon member anggota dengan Kartu Tanda Penduduk (KTP)-nya.

Konsep yang dipakai oleh aplikasi Vtube ini hampir sama dengan konsep yang dimiliki oleh platform YouTube dan Google AdSense, yang telah dikenal dan diakui oleh seluruh dunia dan tetap eksis hingga saat ini. Konsep yang digunakan oleh aplikasi Vtube ini adalah:

1. Pada strategi pemasaran awalnya aplikasi Vtube ini yaitu mengajak orang lain untuk menjadi member atau anggota.

2. Member atau anggota awal ini selanjutnya mengajak orang lain juga untuk ikut menjadi anggota ( begitu seterusnya).

3. Awal pendaftaran menjadi member atau anggota itu gratis akan tetapi harus memperpanjang keanggotaan dan jika menginginkan hasil yang lebih harus upgrade atau harus menaikkan level keanggotaan atau member.

4. Perpanjangan upgrade atau kenaikan level ini berbayar sesuai dengan level yang diinginkan. Upgrade atau kenaikan level ini Vtube menawarkan sistem paket bintang dengan level bintang 1 sampai dengan bintang enam. Dan itupun harus diperpanjang setiap 40 hari. Jadi dapat disimpulkan bahwa aplikasi Vtube juga mendapatkan penghasilan dari pembelian paket sistem bintang.

5. Dalam pemasangan iklan, member atau anggota lah yang memasangkan iklannya (bukan perusahaan besar yang memasangkan iklan).

6. Tugas dari member atau anggota ini hanya menonton video dan iklan yang ada di aplikasi Vtube saja.

7. Dan untuk member atau anggota yang mengajak orang lain untuk bergabung akan mendapatkan bonus berupa Royalty poin dari aplikasi Vtube. ${ }^{6}$

Kemudian cara kerja untuk menghasilkan uang dari Vtube adalah dengan cara selama 40 hari member Vtube harus menonton video dan iklan minimal selama 5 detik dan member harus menyelesaikan misi untuk bisa mendapatkan 1 poin dimana nilai 1 poin tersebut adalah 1 dollar. Jika ingin mencairkan poin Vtube ini maka member atau anggota harus menjual terlebih dahulu poin yang dimilikinya dan menunggu sampai ada member atau anggota lain yang ingin membelinya di leadingoutsource.com dan minimal poin yang dapat dijual atau dicairkan yaitu 5 poin pertransaksi dan ada biaya pemotongan atau fee yang harus dibayar.

\section{Faktor penyebab yang melatarbelakangi aplikasi Vtube disebut sebagai investasi ilegal}

Aplikasi Vtube merupakan suatu aplikasi yang dikeluarkan oleh PT. Future View Tech yang menjalankan bisnis aplikasinya menggunakan bisnis periklanan digital. Kantor Vtube ini berada di Gedung Kinanti Building Lantai 2, Jalan Epicentrum No. 3 Kawasan Rasuna Epicentrum Kuningan, Kelurahan Karet Kuningan, Kecamatan Setiabudi, Kotamadya Jakarta Selatan, DKI Jakarta, 62090.

Aplikasi Vtube mempunyai izin Penyelenggara Sistem Elektronik (PSE) yang diterbitkan pada tnggal 10 Maret 2020 dengan masa berlaku sampai dengan 10 Maret 2021. Akan tetapi website resmi Vtube saat ini masuk kedalam daftar entitas ilegal Satgas Waspada Investasi (SWI) pada bulan Juni 2020 yang mengakibatkan website resmi dari Vtube ini sudah tidak bisa lagi terbuka.

\footnotetext{
${ }^{5}$ Eduardus Tendelilin.Analisis Investasi dan Manajemen Portofolio. Edisi 1 Cetakan 1. Yogyakarta:BPFE.2001.hlm.1.

${ }^{6}$ https://www.infoperbankan.com/umum/vtube.html diakses pada tanggal 21 Desember 2020 pukul 15.00 WIB
} 
Tamara Fransisca Jamal dan Puti Priyana, Perlindungan Konsumen Pengguna Investasi Ilegal Vtube Berdasarkan UndangUndang Nomor 21 Tahun 2011 tentang Otoritas Jasa Keuangan

\begin{tabular}{|c|c|c|}
\hline & Entitas & $\begin{array}{l}\text { Kegiatan yang dihentikan } \\
\end{array}$ \\
\hline 1. & Maxwin/Belibisnis.com & $\begin{array}{l}\text { Pendidikan Bisnis, konsultan Bisnis, investasi uang tanpa } \\
\text { izin }\end{array}$ \\
\hline 2. & Nanonetwork (Fingo Indonesia) & $\begin{array}{l}\text { Perdagangan online tanpa izin dengan skema multi level } \\
\text { marketing }\end{array}$ \\
\hline 3. & Hijrah Mulia Sejahtera & $\begin{array}{l}\text { Penawaran investasi tanpa izin dengan skema multi level } \\
\text { marketing atau moneygame dengan janji keuntungan } \\
\text { Rp50.ooo-Rp2.000.000 (lima puluh ribu hingga satu juta } \\
\text { rupiah) per hari }\end{array}$ \\
\hline 4. & Building The Dream (BTD) & Penawaran investasi tanpa izin \\
\hline$\frac{5 .}{6 .}$ & $\begin{array}{l}\text { Komunitas Cerdas Finansial (KCFS) } \\
\text { Taawun }\end{array}$ & $\begin{array}{l}\text { Penawaran investasi atau pelatihan investasi tanpa izin } \\
\text { Penawaran jasa pelunasan utang tanpa izin }\end{array}$ \\
\hline 7. & $\begin{array}{l}\text { Asia Dinasty/PT Asia Dinasty } \\
\text { Sejahtera/Koperasi Asia Dinasty } \\
\text { Sejahtera }\end{array}$ & $\begin{array}{l}\text { Penawaraan investasi tanpa izin dengan imbal hasil yang tetap } \\
\text { (investasi uang) }\end{array}$ \\
\hline 8. & PT Future View Tech (VTube) & 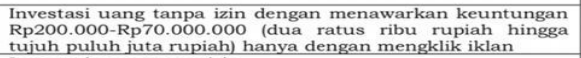 \\
\hline 9. & Attonbank & Investasi uang tanpa izin \\
\hline 10. & Cryptomiracles & $\begin{array}{l}\text { Investasi uang tanpa izin dengan modus crypto asset dan } \\
\text { imbal hasil lima belas persen per bulan }\end{array}$ \\
\hline 11. & Btcindochanger.net & $\begin{array}{l}\text { Perdagangan crypto asset tanpa izin dengan imbal hasil } 20 \text { - } \\
50 \% \text { (dua puluh hingga lima puluh persen) per hari }\end{array}$ \\
\hline 12. & PRIMZ & $\begin{array}{l}\text { Perdagangan crypto asset tanpa izin dengan imbal hasil o, 12- } \\
\text { o,33\% (nol koma dua belas hingga nol koma tiga puluh tiga } \\
\text { persen) per hari }\end{array}$ \\
\hline 13. & $\begin{array}{l}\text { E-Dinar Coin Gold (PT Indragiri Digital } \\
\text { Aset Indonesia) }\end{array}$ & $\begin{array}{l}\text { Dersen/ per hari } \\
\text { Perdagangan berjangka atau crypto asset tanpa izin dengan } \\
\text { imbal hasil tetap }\end{array}$ \\
\hline 14. & & Perdagangan berjangka atau crypto exchanger tanpa izin \\
\hline$\frac{15 .}{16 .}$ & $\frac{T w}{T w}$ & $\begin{array}{l}\text { Perdagangan berjangka komoditi atau Fore } \\
\text { Perdagangan berjangka komoditi atau Fore }\end{array}$ \\
\hline$\frac{16 .}{17 .}$ & $\begin{array}{l}\text { Agea } \\
\text { Alpar } \\
\text { den }\end{array}$ & $\begin{array}{l}\text { Perdagangan berjangka komoditi atau Forex tanpa izin } \\
\text { Perdagangan berjangka komoditi atau Forex tanpa izin }\end{array}$ \\
\hline 18. & & Perdagangan berjangka komoditi atau Forex tanpa izin \\
\hline 19. & & Perdagangan berjangka komoditi atau Forex tanpa izin \\
\hline 20. & An & Perdagangan berjangka komoditi atau Forex tanpa izin \\
\hline 21. & $\begin{array}{l}\text { Anzo Capit } \\
\text { (https:/ / a }\end{array}$ & Perdagangan berjangka komoditi atau Forex tanpa izin \\
\hline$\frac{22 .}{23 .}$ & $\begin{array}{l}\text { Aronex Corp (ht } \\
\text { AT Global Mark }\end{array}$ & $\begin{array}{l}\text { Perdagangan berjangka komoditi atau Forex tanpa izin } \\
\text { Perdagangan berjangka komoditi atau Forex tanpa izin }\end{array}$ \\
\hline 24. & $\begin{array}{l}\text { (Attps://www. at } \\
\text { AVA Trade EU L }\end{array}$ & Perdagangan berjangka komoditi atau Forex tanpa izin \\
\hline 25. & $\frac{(\text { hatteps }}{\text { Axi Tr }}$ & \\
\hline 26. & $\begin{array}{l}\text { Benor } \\
\text { (htttps: }\end{array}$ & Perdagangan berjangka komoditi atau Forex tanpa izin \\
\hline$\frac{27 .}{28 .}$ & $\begin{array}{l}\text { Binom } \\
\text { Bullis\} }\end{array}$ & $\begin{array}{l}\text { Perdag: } \\
\text { Perdag: }\end{array}$ \\
\hline 29. & up, Inc & Perdagangan berjangka komoditi atau Forex tanpa izin \\
\hline 30. & $\begin{array}{l}\text { Exness (hattps:// wwww.promotion- } \\
\text { exness } \\
\text { 888.com) }\end{array}$ & Perdagangan berjangka komoditi atau Forex tanpa izin \\
\hline 31. & $\begin{array}{l}\text { FBS (https://fbsidn, trade) } \\
\text { FirewoodFX Global Markets } \\
\text { (https: //www fwnets.com) }\end{array}$ & $\begin{array}{l}\text { Perdagangan berjangka komoditi atau Forex tanpa izin } \\
\text { Perdagangan berjangka komoditi atau Forex tanpa izin }\end{array}$ \\
\hline 33. & $\begin{array}{l}\text { FXCL } \\
\text { (http://fxclearingcent.blogspot.com// } \\
\text { dan https://www. fxclmarkets.org//) }\end{array}$ & Perdagangan berjangka komoditi atau Forex tanpa izin \\
\hline
\end{tabular}

\begin{tabular}{|c|c|c|}
\hline No. & Entitas & $\begin{array}{l}\text { Kegiatan yang dihentikan } \\
\end{array}$ \\
\hline 34. & $\begin{array}{l}\text { FXOptimax (https://www. fxoptimax- } \\
\text { indonesia.com dan } \\
\text { https://www.fxoptimaxid.net) }\end{array}$ & Perdagangan berjangka komoditi atau Forex tanpa izin \\
\hline 35. & $\begin{array}{l}\text { FXPrimus Group } \\
\text { (https://fxprimusindo.com dan } \\
\text { https://www.fxprimusidn.com) }\end{array}$ & Perdagangan berjangka komoditi atau Forex tanpa izin \\
\hline 36. & FXTM (https://www.fxtmid.com/) & Perdagangan berjangka komoditi atau Forex tanpa izin \\
\hline 37. & Hector Trade (https: / /hectortrade.com) & Perdagangan berjangka komoditi atau Forex tanpa izin \\
\hline 38. & $\begin{array}{l}\text { Hotforex } \\
\text { (https://www.hfindonesia.com/ dan } \\
\text { https://www.hfmtrading.com) }\end{array}$ & Perdagangan berjangka komoditi atau Forex tanpa izin \\
\hline 39. & Iko Global Ltd (https: //www .ikofx.com) & Perdagangan berjangka komoditi atau Forex tanpa izin \\
\hline 40. & $\begin{array}{l}\text { Intertrader } \\
\text { (https://www.intertrader.com/) }\end{array}$ & Perdagangan berjangka komoditi atau Forex tanpa izin \\
\hline 41. & $\begin{array}{l}\text { Intertrader } \\
\text { (https: / www.intertrader.com/) }\end{array}$ & Perdagangan berjangka komoditi atau Forex tanpa izin \\
\hline 42. & $\begin{array}{l}\text { Intertrader } \\
\text { (https://www.intertrader.com/) }\end{array}$ & Perdagangan berjangka komoditi atau Forex tanpa izin \\
\hline 43. & $\begin{array}{l}\text { Landprime Ltd (https: //www.land- } \\
\text { fx.com) }\end{array}$ & Perdagangan berjangka komoditi atau Forex tanpa izin \\
\hline 44. & Lego Market (https://legoforex.co) & Perdagangan berjangka komoditi atau Forex tanpa izin \\
\hline 45. & $\begin{array}{l}\text { Lite Forex Investments Ltd (https://id- } \\
\text { liteforex.com) }\end{array}$ & Perdagangan berjangka komoditi atau Forex tanpa izin \\
\hline 46. & $\begin{array}{l}\text { Market Solution Ltd } \\
\text { (https://maxitrade com/en }\end{array}$ & Perdagangan berjangka komoditi atau Forex tanpa izin \\
\hline 47. & $\begin{array}{l}\text { Market Solution Ltd } \\
\text { (https://maxitrade.com/en/) }\end{array}$ & Perdagangan berjangka komoditi atau Forex tanpa izin \\
\hline 48. & 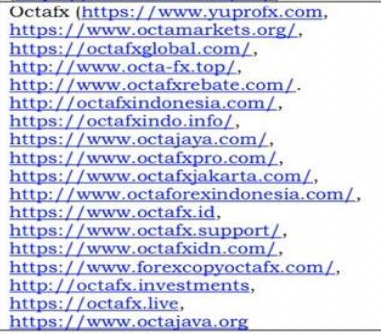 & Perdagangan berjangka komoditi atau Forex tanpa izin \\
\hline 49. & $\begin{array}{l}\text { Premax Capital Ltd } \\
\text { (https://fxpremax.com) }\end{array}$ & Perdagangan berjangka komoditi atau Forex tanpa izin \\
\hline 50. & $\begin{array}{l}\text { PrimeXBT Trading Services Ltd } \\
\text { (https://primexbt.com) }\end{array}$ & Perdagangan berjangka komoditi atau Forex tanpa izin \\
\hline 51. & $\begin{array}{l}\text { Roboforex Limited (https://www.robo- } \\
\text { indonesia.com) }\end{array}$ & Perdagangan berjangka komoditi atau Forex tanpa izin \\
\hline 52. & $\begin{array}{l}\text { TIO Markets Limited } \\
\text { (https://tiomarkets.com/) }\end{array}$ & Perdagangan berjangka komoditi atau Forex tanpa izin \\
\hline 53. & $\begin{array}{l}\text { XM Global Limited (https://www.xm- } \\
\text { asian.com/) }\end{array}$ & Perdagangan berjangka komoditi atau Forex tanpa izin \\
\hline 54. & $\begin{array}{l}\text { XSocio Markets Limited } \\
\text { (https://xsocio.com) }\end{array}$ & Perdagangan berjangka komoditi atau Forex tanpa izin \\
\hline 55. & Yadix (https://www.yadix.com) & Perdagangan berjangka komoditi atau Forex tanpa izin \\
\hline 56. & $\begin{array}{l}\text { ZT Market Limited } \\
\text { (https://zentrade.com) }\end{array}$ & Perdagangan berjangka komoditi atau Forex tanpa izin \\
\hline 57. & AVA Trade (https://www.avatrade.id) & Perdagangan berjangka komoditi atau Forex tanpa izin \\
\hline 58. & ATFX (https: //www.atfx.id) & Perdagangan berjangka komoditi atau Forex tanpa izin \\
\hline 59. & $\begin{array}{l}\text { Instaforex Partner (Rebate) } \\
\text { (https://newprimafx.com) }\end{array}$ & Perdagangan berjangka komoditi atau Forex tanpa izin \\
\hline 60 & GMIEDGE FX (https://gmi & \\
\hline
\end{tabular}


Tamara Fransisca Jamal dan Puti Priyana, Perlindungan Konsumen Pengguna Investasi Ilegal Vtube Berdasarkan UndangUndang Nomor 21 Tahun 2011 tentang Otoritas Jasa Keuangan

\begin{tabular}{|c|c|c|}
\hline No. & Entitas & Kegiatan yang dihentikan \\
\hline 61. & $\begin{array}{l}\text { Salmamarket } \\
\text { (https://www.salmamarket.com) }\end{array}$ & Perdagangan berjangka komoditi atau Forex tanpa izin \\
\hline 62. & Tradestoind (https://tradestoind.com) & Perdagangan berjangka komoditi atau Forex tanpa izin \\
\hline 63. & $\begin{array}{l}\text { Garuda Investasi } \\
\text { (https://www.garudavest.com) }\end{array}$ & Perdagangan berjangka komoditi atau Forex tanpa izin \\
\hline 64. & $\begin{array}{l}\text { PT. INVESTASI TAMA } \\
\text { (https://www.investasitama.com) }\end{array}$ & Perdagangan berjangka komoditi atau Forex tanpa izin \\
\hline 65. & Tukar Duit (http://www.tukarduit.id/) & Perdagangan berjangka komoditi atau Forex tanpa izin \\
\hline 66. & Insta Forex (http://familyinstafx.co.id) & Perdagangan berjangka komoditi atau Forex tanpa izin \\
\hline 67. & Euromax (https://www.euromax.id/) & Perdagangan berjangka komoditi atau Forex tanpa izin \\
\hline 68. & Oke Fx (https://www.okefx.com) & Perdagangan berjangka komoditi atau Forex tanpa izin \\
\hline 69. & BFX Rebate (https://bfxrebate.id) & Perdagangan berjangka komoditi atau Forex tanpa izin \\
\hline 70. & $\begin{array}{l}\text { Alpari Trading } \\
\text { (https://www.alparitrading.com) }\end{array}$ & Perdagangan berjangka komoditi atau Forex tanpa izin \\
\hline 71. & FBS (https://id-fbs.trade/) & Perdagangan berjangka komoditi atau Forex tanpa izin \\
\hline 72. & Olymptrade (https://i-olymptrade.com/) & Perdagangan berjangka komoditi atau Forex tanpa izin \\
\hline 73. & InspiraFx (https://inspirafx.com/) & Perdagangan berjangka komoditi atau Forex tanpa izin \\
\hline 74. & $\begin{array}{l}\text { IDS Kapital Ltd } \\
\text { (https://idskapital.com/) }\end{array}$ & Perdagangan berjangka komoditi atau Forex tanpa izin \\
\hline 75. & BD Swiss (https://www.bdswiss.com/) & Perdagangan berjangka komoditi atau Forex tanpa izin \\
\hline 76. & $\begin{array}{l}\text { Insta Forex (https://proifx.net/. } \\
\text { https://ifx.money/, } \\
\text { http://www.gopundi.com/, } \\
\text { https://www.instafxdeal.com) }\end{array}$ & Perdagangan berjangka komoditi atau Forex tanpa izin \\
\hline 77. & FXOpen (https://www.tradefxid.com/) & Perdagangan berjangka komoditi atau Forex tanpa izin \\
\hline 78. & Weltrade (https://weltrade.online/) & Perdagangan berjangka komoditi atau Forex tanpa izin \\
\hline 79. & $\begin{array}{l}\text { MRG Premiere } \\
\text { (https://mrgpremieretrade.net/) }\end{array}$ & Perdagangan berjangka komoditi atau Forex tanpa izin \\
\hline 80. & $\begin{array}{l}\text { MRG Trade } \\
\text { (https://www.mrgforex.trade/) }\end{array}$ & Perdagangan berjangka komoditi atau Forex tanpa izin \\
\hline 81. & Tickmill(https://www.tickmill.sc/) & Perdagangan berjangka komoditi atau Forex tanpa izin \\
\hline 82. & Golden Fx (www.golden-fx.com) & Perdagangan berjangka komoditi atau Forex tanpa izin \\
\hline 83. & Just Forex (https://justforexid.com) & Perdagangan berjangka komoditi atau Forex tanpa izin \\
\hline 84. & $\begin{array}{l}\text { Salma Markets } \\
\text { (www.salmamarkets.trade) }\end{array}$ & Perdagangan berjangka komoditi atau Forex tanpa izin \\
\hline 85. & Merit Forex (www.meritforex.com) & Perdagangan berjangka komoditi atau Forex tanpa izin \\
\hline 86. & $\begin{array}{l}\text { Seputar Forex } \\
\text { (https://www.seputarforex.com) }\end{array}$ & Perdagangan berjangka komoditi atau Forex tanpa izin \\
\hline 87. & $\begin{array}{l}\text { XM Global } \\
\text { (https://www.xmworldwide.com) }\end{array}$ & Perdagangan berjangka komoditi atau Forex tanpa izin \\
\hline 88. & Exness (https://www.exness.markets) & Perdagangan berjangka komoditi atau Forex tanpa izin \\
\hline 89. & Alvexo (https://www.alvexo.com/) & Perdagangan berjangka komoditi atau Forex tanpa izin \\
\hline 90. & $\begin{array}{l}\text { Squared Financial } \\
\text { (https://squaredfinancial.com/) }\end{array}$ & Perdagangan berjangka komoditi atau Forex tanpa izin \\
\hline 91. & Libertex (https://libertex.com) & Perdagangan berjangka komoditi atau Forex tanpa izin \\
\hline 92. & $\begin{array}{l}\text { Aetos Capital Group } \\
\text { (https://www.aetoscg.com) }\end{array}$ & Perdagangan berjangka komoditi atau Forex tanpa izin \\
\hline 93. & Just2Trade (https://just2trade.online) & Perdagangan berjangka komoditi atau Forex tanpa izin \\
\hline 94. & Skilling (https://skilling.com) & Perdagangan berjangka komoditi atau Forex tanpa izin \\
\hline 95. & OInvest (https://lp-oinvest.com) & Perdagangan berjangka komoditi atau Forex tanpa izin \\
\hline 96. & Investing (https://www.investing.com/) & Perdagangan berjangka komoditi atau Forex tanpa izin \\
\hline 97. & Europe Fx (https://europefx.com/) & Perdagangan berjangka komoditi atau Forex tanpa izin \\
\hline 98. & Trading.Com (https://www trading.com) & Perdagangan berjangka komoditi atau Forex tanpa izin \\
\hline 99. & NBH Markets (https://nbhm.com) & Perdagangan berjangka komoditi atau Forex tanpa izin \\
\hline
\end{tabular}

Saat ini Vtube dinyatakan sebagai investasi ilegal berdasarkan siaran pers Satgas Waspada Investasi (SWI) No. SP 06/SWI/VII/2020 tertanggal 3 Juli 2020 dikarenakan tidak memiliki izin dan berpotensi merugikan para penggunanya. Vtube adalah suatu perusahaan yang sudah memiliki Izin Usaha Industri (IUI) yang keluar pada tanggal 18 Januari 2020. Akan tetapi Izin Usaha Industri (IUI) yang dimiliki oleh Vtube tidak sesuai dengan praktik usaha yang dilaksanakannya. Izin Usaha Industri (IUI) yang dimiliki oleh Vtube adalah suatu kegiatan atau aktivitas teknologi dan jasa komputer lainnya dengan nomor KBLI 62090. KBLI 62090 ini sebenarnya adalah Izin Usaha Industri (IUI) untuk usaha pemasangan, perakitan, instalasi dan servis komputer sedangkan Vtube sendiri saat ini menjalankan usaha advertising atau perikalan, yang seharusnya memiliki nomor 73100 .

Izin usaha Vtube seharusnya sudah di cabut sesuai dengan Peraturan Pemerintah Republik Indonesia Nomor 13 Tahun 1995 Tentang Izin Usaha Industri. Pada Pasal 10 tentang pencabutan izin, IUI dapat dicabut dalam hal:

Pasal 10 ayat 4 :

"Perusahaan Industri yang melakukan kegiatan usaha industri tidak sesuai dengan ketentuan yang ditetapkan dalam izin yang diperolehnya."

Pasal 10 ayat 5:

"Perusahaan industri yang tidak menyampaikan informasi industri atau dengan sengaja menyampaikan informasi industri yang tidak benar." 7

Maka sebenarnya izin vtube sudah tidak berlaku lagi karena melakukan kegiatan yang tidak sesuai dengan ketentuan Pasal 10 ayat (4) dan ayat (5) tentang pencabutan izin.

\footnotetext{
${ }^{7}$ Peraturan Pemerintah Republik Indonesia Nomor 13 Tahun 1995 Tentang Izin Usaha Industri
} 


\section{Peran Otoritas Jasa Keuangan dalam memeberikan perlindungan hukum kepada pengguna aplikasi Vtube}

Otoritas Jasa Keuangan (OJK) merupakan suatu lembaga independen yang terbebas dari campur tangan lembaga lainnya yang memiliki fungsi, tugas dan wewenang pengaturan, pengawasan, pemeriksaan dan penyidikan terhadap seluruh kegiatan yang ada didalam sektor jasa keuanga. Baik dari sektor perbankan, pasar modal dan sektor jasa keuangan non-bank seperti asuransi,dana pensiun, lembaga pembiayaan, fintech dan lembaga jasa keuangan lainnya.

Otoritas Jasa Keuangan (OJK) juga memiliki fungsi sebagai lembaga pengambil keputusan terkait perkembangan dan kemajuan keuangan serta perlindungan konsumen. Selain itu, Otoritas Jasa Keuangan (OJK) juga bertugas memberikan perlindungan terhadap konsumen salah satunya di bidang investasi karena pada masa ini maraknya investasi ilegal yang meresahkan masyarakat. Salah satu investasi ilegal yang sedang banyak perbincangkan ialah investasi berbasis aplikasi Vtube, seperti yang telah dibahas didalam subbab sebelumnya bahwa aplikasi Vtube merupakan aplikasi investasi ilegal sesuai dengan lampiran daftar entitas yang dikeluarkan oleh Otoritas Jasa Keuangan (OJK) tertanggal 3 Juni 2020.

Perlindungan hukum yang diberikan oleh Otoritas Jasa Keuangan (OJK) terhadap konsumen diatur didalam Pasal 4 huruf c Undang-Undang nomor 21 tahun 2011 tentang Otoritas Jasa Keuangan (OJK) yang berbunyi : “ Otoritas Jasa Keuangan (OJK) Mampu melindungi kepentingan konsumen dan masyarakat".

Perlindungan konsumen di bidang jasa keuangan bertujuan untuk mewujudkan sistem perlindungan konsumen yang efektif, meningkatkan kualitas pemberdayaan konsumen dan menciptakan kesadaran pelaku usaha jasa keuangan terkait pentingnya perlindungan konsumen sehingga dapat meningkatkan kepercayaan masyarakat selaku konsumen dalam sektor keuangan. Perlindungan konsumen yang diberikan oleh Otoritas Jasa Keuangan (OJK) dianggap sangat diperlukan dikarenakan lalu lintas dalam sektor jasa keuangan khususnya dalam hal ini investasi semakin luas dan intens. Perlindungan konsumen yang diberikan Otoritas Jasa Keuangan (OJK) ini diatur didalam Pasal 28 sampai dengan Pasal 30 Undang-undang Otoritas Jasa Keuangan (UUOJK).

Pasal 28 mengatur tentang perlindungan konsumen dan masyarkat, OJK berwenang untuk melakukan tindakan pencegahan kerugian Konsumen dan Masyarakat, meliputi:

a. Memberikan informasi dan edukasi kepada masyarakat mengenai karakteristik sektor jasa keuangan, layanan, dan produknya;

b. Meminta Lembaga Jasa Keuangan untuk menghentikan kegiatannya apabila kegiatan tersebut berpotensi merugikan masayarakat;

c. Tindakan lain yang dianggap perlu sesuai dengan ketentuan peraturan perundang-undangan di sektor jasa keuangan.

Pasal 29 OJK melakukan pelayan pengaduan Konsumen yang meliputi:

a. Menyiapkan perangkat yang memadai untuk pelayanan pengaduan konsumen yang dirugikan oleh pelaku di lembaga jasa keuangan;

b. Membuat mekanisme pengaduan konsumen yang dirugikan oleh pelaku di Lembaga Jasa Keuangan.

c. Memfasilitasi penyelesaian pengaduan konsumen yang dirugikan oleh pelaku di lembaga jasa keuangan sesuai dengan peraturan perundang-undangan di sektor jasa keuangan.

Pasal 30 OJK, meliputi :

1. Untuk perlindungan konsumen dan masyarakat OJK berwenang melakukan pembelaan hukum, yang meliputi:

a. Memerintahkan atau melakukan tindakan tertentu kepada Lembaga Jasa Keuangan untuk menyelesaikan pengaduan konsumen yang dirugikan oleh Lembaga Jasa Keuangan dimaksud;

b. Mengajukan gugatan;

(1) Untuk memperoleh kembali harta kekayaan milik pihak yang dirugikan, baik yang berada dibawah penguasaan pihak yang menyebabkan kerugiaan dimaksud maupun dibawah penguasaan pihak lain dengan itikad tidak baik; dan/atau

(2) Untuk memperoleh ganti kerugian dari pihak yang menyebabkan kerugian terhadap konsumen dan/atau Lembaga Jasa Keuangan sebagai akibat dari pelanggaran atas peraturan perundang-undangan di sektor jasa keuangan.

2. Ganti kerugian sebagaimana yang dimaksud pada ayat (1) huruf b angka 2 hanya digunakan untuk pembayaran ganti kerugian terhadap pihak yang dirugikan. ${ }^{8}$

\footnotetext{
${ }^{8}$ Undang-undang nomor 21 Tahun 2011 Tentang Otoritas Jasa keuangan
} 
Tamara Fransisca Jamal dan Puti Priyana, Perlindungan Konsumen Pengguna Investasi Ilegal Vtube Berdasarkan UndangUndang Nomor 21 Tahun 2011 tentang Otoritas Jasa Keuangan

Perlindungan Konsumen yang diberikan Otoritas Jasa Keuangan (OJK) selain diatur dalam Undang-Undang No. 21 Tahun 2011 juga diatur dalam Peraturan Otoritas Jasa Keuangan Nomor; 1/POJK.07/2013 tentang Perlindungan Konsumen Sektor Jasa Keuangan. Selanjutnya dalam memberikan perlindungan hukum bagi pengguna aplikasi Vtube (aplikasi investasi ilegal) Otoritas Jasa Keuangan (OJK) memberikan beberapa tindakan sebagai berikut:

\section{Tindakan Preventif (Tindakan Pencegahan)}

Tindakan prevefentif yang diberikan Otoritas Jasa Keuangan (OJK) dalam mengantisipasi dan mencegah masyarakat Indonesia terjebak dalam investasi ilegal, yaitu:

1. Mengadakan sosialisasi dan edukasi kepada masyarakat tentang karakter dari investasi.

2. Masyarakat harus memastikan terlebih dahulu izin operasional dari investasi yang akan diikutinya.

3. Mengoptimalisasi fungsi layanan konsumen keuangan yang terintegrasi atau Integrated Financial Customer Care (IFCC) yang merupakan salah satu sarana layanan pengaduan Konsumen yang diberiakan OJK.

4. OJK mengeluarkan aturan pelaksana penawaran produk dan/ atau Layanan Jasa Keuangan. Nomor 12/SEOJK.07/2014 tentang Penyampaian Informasi dalam rangka pemasaran produk dan atau layanan jasa keuangan. Surat edaran ini merupakan aturan pelaksanaan dari Peraturan Otoritas jasa Keuangan Nomor 1/POJK.07/2013 tanggal 6 Agustus 2013 tentang Perlindungan Konsumen Sektor Jasa Keuangan yang berlaku efektif sejak 6 Agustus 2014. Surat edaran ini mengatur bahwa penawaran bahwa PUJK harus menggunakan data yang telah disetujui oleh Konsumen atau masyarakat yang bersedia atau dihubungi melalui SMS, telepon, dan/atau email.

5. Peningkatan pengetahuan tentang keuangan oleh masyarakat.

\section{Tindakan Represif (Tindakan Penanganan)}

Tindakan represif ini dilakukan oleh OJK apabila telah terjadi suatu invetasi yang merugikan investor dan masyarakat, yaitu:

1. Pembentukan Satuan Tugas (SATGAS) Waspada Investasi. Berdasarkan Surat Keputusan Ketua Bapepam-LK Nomor: Kep-208/BL/2007 yang ditetapkan tanggal 20 Juni 2007 dan diperpanjang dengan dengan Surat Keputusan Ketua Bappepam-LK Nomor:Kep-124/BL/2012 yang ditetapkan pada tanggal 19 Maret 2012, dibentuk Satuan Tugas Penanganan Dugaan Tindakan Melawan Hukum di Bidang Pengelolaan Investasi.

2. Pembentukan Investor Protection Fund (IPF) oleh OJK atau dana perlindungan modal yang merupakan lembaga perlindungan investor, khususnya di bidang pasar modal.

3. Menerbitkan Peraturan Otoritas Jasa Keuangan (OJK) Nomor 1/POJK.07/2013 tentang Perlindungan konsumen Sektor Jasa Keuangan. Peraturan ini dijadikan sebagai acuan oleh masyarakat untuk mengetahui industri keuangan apa saja yang berada dalam pengawasan OJK.

4. Penyelesaian sengketa di sektor jasa keuangan dapat dilakukan melalui pengaduan dan apabila tidak terselesaikan, maka penyeselaian sengketa tersebut dapat diteruskan ke pengadilan atau ke Lembaga Alternatif Penyelesaian Sengketa (LAPS). ${ }^{9}$

\section{SIMPULAN}

1. Aplikasi Vtube merupakan suatu aplikasi yang dikeluarkan oleh PT. Future View Tech yang menjalankan bisnis aplikasinya menggunakan bisnis periklanan digital. Aplikasi Vtube dinyatakan sebagai investasi ilegal berdasarkan siaran pers Satgas Waspada Investasi (SWI) No.SP 06/SWI/VII/2020 tertanggal 3 Juli 2020 dikarenakan tidak memiliki izin dan berpotensi merugikan para penggunanya. Vtube adalah suatu perusahaan yang sudah memiliki Izin Usaha Industri (IUI) yang keluar pada tanggal 18 Januari 2020. Akan tetapi Izin Usaha Industri (IUI) yang dimiliki oleh Vtube tidak sesuai dengan praktik usaha yang dilaksanakannya. Izin Usaha Industri (IUI) yang dimiliki oleh Vtube adalah suatu kegiatan atau aktivitas teknologi dan jasa komputer lainnya dengan nomor KBLI 62090. KBLI 62090 ini sebenarnya adalah Izin Usaha Industri (IUI) untuk usaha pemasangan, perakitan, instalasi dan servis komputer sedangkan Vtube sendiri saat ini menjalankan usaha advertising atau perikalan, yang seharusnya memiliki nomor 73100. Izin usaha Vtube seharusnya sudah di cabut sesuai dengan Peraturan Pemerintah Republik Indonesia Nomor 13 Tahun 1995 Tentang Izin Usaha Industri.

2. Otoritas Jasa Keuangan (OJK) juga bertugas memberikan perlindungan terhadap konsumen di bidang investasi karena pada masa ini maraknya investasi ilegal yang meresahkan masyarakat. Salah satu investasi ilegal yang sedang banyak perbincangkan ialah investasi berbasis aplikasi Vtube yang termasuk ke dalam salah satu daftar aplikasi investasi ilegal sesuai dengan lampiran daftar entitas yang dikeluarkan oleh Otoritas Jasa Keuangan

${ }^{9}$ Dian Husna Fadlia,Yunanto. "PERAN OTORITAS JASA KEUANGAN (OJK) DALAM PERLINDUNGAN HUKUM BAGI INVESTOR ATAS DUGAAN INVESTASI FIKTIF”. Jurnal Law Reform. Volume 11,Nomor 2, Tahun 2015. Hlm $210-213$. 
tertanggal 3 Juni 2020. Perlindungan konsumen yang diberikan Otoritas Jasa Keuangan (OJK) ini diatur didalam Pasal 28 sampai dengan Pasal 30 Undang-undang Otoritas Jasa Keuangan (UUOJK). Perlindungan Konsumen yang diberikan Otoritas Jasa Keuangan (OJK) selain diatur dalam Undang-Undang No. 21 Tahun 2011 juga diatur dalam Peraturan Otoritas Jasa Keuangan Nomor; 1/POJK.07/2013 tentang Perlindungan Konsumen Sektor Jasa Keuangan. Otoritas Jasa Keuangan dalam memberikan perlindungan hukum bagi pengguna aplikasi Vtube (aplikasi investasi ilegal) Otoritas Jasa Keuangan (OJK) memberikan beberapa tindakan yaitu tindakan preventif dan tindakan refresif.

\section{DAFTAR PUSTAKA}

\section{Buku}

Eduardus Tendelilin. 2001. Analisis Investasi dan Manajemen Portofolio. Edisi 1 Cetakan 1. Yogyakarta:BPFE.

Hasan Shadily, dkk. 2011. Hukum Investasi dan Pasar Modal, Jakarta:Sinar Grafika.

Roni Hanitijo Soemitro.1994. Metode Penelitian Hukum dan Jurimetri, Jakarta: Ghalia Indonesia.

Soerdjono Soekanto, dkk. 1994. Penelitian Hukum Normatif Suatu Tinjauan Singkat. Jakarta: Raja Grafindo Persada.

\section{Jurnal}

Dian Husna Fadlia,Yunanto. "PERAN OTORITAS JASA KEUANGAN (OJK) DALAM PERLINDUNGAN HUKUM BAGI INVESTOR ATAS DUGAAN INVESTASI FIKTIF”. Jurnal Law Reform. Volume 11,Nomor 2, Tahun 2015

Fitria Rahmadani, Paramita Prananingtyas, Siti Mahmudah. "PERLINDUNGAN HUKUM TERHADAP INVESTOR OLEH OTORITAS JASA KEUANGAN DALAM HAL TERJADI INVESTASI ILEGAL (STUDI KASUS PT GOLDEN TRADERS INDONESIA SYARIAH)”. DIPONEGORO LAW REVIEW. Volume 5, Nomor 2, Tahun 2016.

\section{Sumber Internet}

https://www.infoperbankan.com/umum/vtube.html diakses pada tanggal 21 Desemeber 2020 pukul 15.00 WIB

\section{Peraturan Perundang-undangan}

Undang-undang nomor 21 Tahun 2011 Tentang Otoritas Jasa keuangan

Peraturan Pemerintah Republik Indonesia Nomor 13 Tahun 1995 Tentang Izin Usaha Industri 